\title{
Quality of Blue swimming crab Portunus pelagicus Larvae from Domesticated Broodstock
}

\author{
Dody Dharmawan Trijuno*, Yushinta Fujaya, Agviranti, and Syamsurya Marhama \\ Department of Fisheries, Faculty of Marine Science and Fisheries, Hasanuddin University, Kampus UNHAS Tamalanrea \\ Makassar 90245, INDONESIA \\ Correspondence to: dodytrijuno@gmail.com; yushinta.fmuskar@gmail.com
}

\begin{abstract}
Dody Dharmawan Trijuno, Yushinta Fujaya, Agviranti, and Syamsurya Marhama. 2015. Quality of Blue swimming crab Portunus pelagicus Larvae from Domesticated Broodstock. Aquacultura Indonesiana, 16 (1): 22-28. Blue swimming crab (Portunus pelagicus) is the important world fishery resource, but the crab larval rearing faces high mortality problem. The aim of the research was to compare survival and growth rate of larvae resulted from wild and domesticated broodstock blue swimming crab. Domesticated and wild broodstock were used to produce larvae. Domesticated broodstock was selected from repeated reared crab until third generation. Selection of the broodstock mainly based on the survival and growth rate. The wild broodstock was collected from Makassar Strait Sea. Larvae from the two sources of broodstock were reared in the conical tanks with density of 50 zoeas per liter. After reaching megalopa phase, then, the larvae were transferred into concrete tank completed with shelter and it were reared until crab phase. Crab phase was reared for $18 \mathrm{~d}$, then these seed were released into the brackishwater pond for further domestication step. Larva from zoea to crab were fed with rotifer, artemia, fresh small shrimp and diet. The result showed that domesticated broodstock produced higher survival rate $(P<0.05)$ larvae, faster larval stage changes $(P<0.01)$ and uniform larval growth compared to the larvae from wild broodstock. It is clearly shown, the use of domesticated broodstock of blue swimming crab produced better larva quality and quantity than the wild broodstoock crab.
\end{abstract}

Keywords : Blue swimming crab; Broodstock selection; Domestication; Faster growth; Larvae

\section{Introduction}

Blue swimming crabs (Portunus pelagicus) is the world fishery resources with high market demand. This animal has a characteristic blue color of the swimming legs with spots on the carapace, especially for males and generally greenish to brown with or without faint white spots for female (Lai et al., 2010). The size of male crab reaches a maximum carapace width of $20 \mathrm{~cm}$, but commonly caught at size of $14 \mathrm{~cm}$. Based on the FAO book the crab was named as Blue Swimming Crab with taksonomic code: 2311100401. FAO (2014) reported that since 1999 , total catches for these species reached 133,938 and in 2010 nearly 200,000 ton.

High market demand is a challenge for the development of blue crab aquaculture (Romano and Zeng, 2008). According to Williams and Primavera (2001), the type of crab which is potential to be developed as an aquaculture animals are Portunus and Charibdis. Compared to the fourth species of Scylla that has a very aggressive behavior, the Portunids crab is easier to be handled. This crab can spawn in the tanks or in the rearing pond, it can grow to the broodstock size, and the crab does not easily escape across the pond dike. However, the major challenge is high level of cannibalism during larval rearing and grow-out. Cannibalism increased when uneven growth occurs during rearing period. Thus, uniform molting and growth could be one way to reduce cannibalism.

Based on the authors experience, that crab rearing using wild seed, the growth was low and uneven, and high mortality occurred. In addition, the quality of crab meat was soft with greenish or reddish color. This condition was below the international standard market. Therefore, domestication of blue crab is one possible solution to support sustainable blue crab aquaculture. According to Hale (1969), domestication is a condition in which the reproduction, rearing and feeding an organism under human control. In aquaculture, domestication is regarded as acclimatization of an aquatic organism to the rearing condition emphasizes in the two main characters namely rapid growth and ability to spawn in the captivity. (Hassin et al., 1997).

Learning from the success of Penaeus vannamei domestication and breeding effort which started in 1997, it has been increasingly the growth of the shrimp industry very quickly especially dissemination to Asia. Through this revolution, world aquaculture production of 
Penaeus vannamei shrimp increased from only $10 \%$ of the total shrimp production in 1998 to $75 \%$ of the total shrimp production in 2006. Shrimp revolution in Thailand was characterized by the use of derivatives domesticated faster growth and disease resistant P.vannamei (Wyban, 2007).

This domestication study is part of many steps of blue crab domestication program. The blue crab domestication was conducted in combination with selection of fast growing individu has been doing in order to obtain excellent crab broodstock which may produce qualified larva for aquaculture.

This research was conducted to evaluate larva quality from wild and domesticated blue crab broodstock. Larval survival rate, larval phase changes, and strategy in applying domesticated broodstock for development of sustainable crab aquaculture are discussed.

\section{Materials and methods}

\section{Broodstock collection}

Domesticated broodstock (mean $\mathrm{CW}$ $101.9 \mathrm{~mm}$ ) derived from the education pond Hasanuddin University in Barru Regency, South Sulawesi Indonesia, while wild broodstock (mean CW $128 \mathrm{~mm}$ ) was collected from the fisherman where the crab caught in the area of Barru Regency, Makassar Strait waters. Initial, domestication was performed by hatching the eggs of wild female collected from the same area started from 2013. The larvae were reared in the hatchery of Hasanuddin University, then the crab seeds were transferred and grew-out at the Hasanuddin University pond. After 3 mo rearing, the crabs were selected as candidate for broodstock. Only the crabs that have above the average growth rate were selected. The crabs that have carapace width more than $100 \mathrm{~mm}$ were collected and it were further reared to be broodstock. This domestication was repeatedly until three generation. Broodstock from the third generation were used in this research. Domesticated male and female broodstocks were reared in the concrete tank with sand substrate until they spawned.

\section{Hatching and larval rearing}

Hatching of crab eggs were conducted in the $250 \mathrm{~L}$ conical tank in the Hatchery of Hasanuddin University in Barru Regency, South
Sulawesi, Indonesia. The new hatched larva was selected based on their respond to the light. Only the larvae that come closer to the light were used in the study. The selected larvae were then transferred into the $250 \mathrm{~L}$ conical tank for $18 \mathrm{~d}$ rearing period or when they reached megalopa phase. Then, the megalopa phase were transferred again into 4 ton concrete tank which completed with plastic band as shelter. The megalopa crab were reared until crab phase. The crab larvae from zoea to crab phases were fed on rotifer, nauplii artemia and artificial diets (Table 1). Artificial diet used was commercial shrimp diet with protein content of $40.37 \%$, fat $8.56 \%$ and carbohydrate $28.57 \%$. Larval feeding was conducted twice and six times a day for life food and diet, respectively.

The sea water used for larval rearing was serially treated through sand filter, $50 \mathrm{mg} / \mathrm{L}$ chlorine, then it was neutralized with $25 \mathrm{mg} / \mathrm{L}$ sodium tiosulphate and finally it was flowed through ultra violet lamp. Water quality parameters in the larval rearing tank were kept nearly stable at $28^{\circ} \mathrm{C}, 32 \%$ and $4 \mathrm{mg} / \mathrm{L}$ for temperature, salinity and oxygen, respectively. Water exchange was conducted only $20 \%$ every $3 \mathrm{~d}$ to prevent larval stress because of changes of environmental condition.

\section{Experimental design and data analysis}

Experiment was conducted with two treatments group of larvae from domesticated broodstock and wild broodstock. Each group of larvae was replicated twelve times. Each group of larvae from each broodstock source was reared in the twelve conical fiberglass tanks. Observation was conducted on the survival rate and larval stages index (LSI). Survival rate of the larvae at the end of rearing was calculated by the formula : survival rate $(\%)=($ total number of survived larvae / Initial number of larvae) x 100. Larval stage index was calculated based on Redzuari et al. $(2012)$ by the ISL formula $=\left[\left(\mathrm{Z}_{\mathrm{o}} \times \mathrm{N}_{\mathrm{o}}\right)+\left(\mathrm{Z}_{\mathrm{t}} \mathrm{x}\right.\right.$ $\left.\left.\mathrm{N}_{\mathrm{t}}\right)\right] / \mathrm{N}$; Zo : Zoea stage, No : number of zoea at Zo stage, $\mathrm{Zt}$ : next stage of the previous zoea, $\mathrm{Nt}$ : number of zoea in next stage of the previous zoea, $\mathrm{N}$ : total number of larvae in sample. Morphological observation of the crab followed Fujaya et al. (2014) (Table 2). Differences of survival rate during zoea phase and larval stage index of the larva among the two sources of broodstocks were analysed by t Test. 
Table 1. Type and amount of food given during the crab larval rearing

\begin{tabular}{lcccccc}
\hline \multirow{2}{*}{ Type of food } & \multicolumn{5}{c}{ Larvae stages } \\
\cline { 2 - 7 } & Zoea-1 & Zoea-2 & Zoea-3 & Zoea-4 & Megalopa & Crab \\
\hline Rotifers (Brachionus spp.) (Ind /mL) & 20 & 20 & 20 & & 2 & 2 \\
Artemia nauplii (ind/mL) & 2.5 & 5 & 7.5 & 10 & 15 & \\
Artificial feed (mg/L/d) & & & & & 10 \\
Chopped mysid shrimp (g/d) & & & & & \\
\hline
\end{tabular}

Table 2. A morphological characteristics and ranges of Larval stages index (LSI) of blue crab larva

\begin{tabular}{llc}
\hline \multicolumn{1}{c}{ Larva stages } & \multicolumn{1}{c}{ Morphological characteristics } & LSI \\
\hline Zoea-1 (Z1) & $\begin{array}{l}\text { Sessile eyes with five abdominal segments } \\
\text { Zoea-2 (Z2) }\end{array}$ & $\begin{array}{l}\text { Stalked eye with five abdominal segments } \\
\text { Zoea-3 (Z3) }\end{array}$ \\
$\begin{array}{l}\text { Stalked eye-with six segments of the abdomen; pleopod bud appeared on } \\
\text { the inside of the abdominal segments }\end{array}$ & $>1-2$ \\
Zoea-4 (Z4) & $\begin{array}{l}\text { Stalked eye with six segments of the abdomen; pleopod fully developed } \\
\text { on the inside of the abdominal segments }\end{array}$ & $>3-4$ \\
Megalopa (M) & $\begin{array}{l}\text { Claws fully developed, body shape more like a crab but the abdomen still } \\
\text { extends to the rear }\end{array}$ & $>4-5$ \\
Crab (C) & Whole body similar to adult crabs & $>5-6$ \\
\hline
\end{tabular}

\section{Results and discussions}

Both wild and domesticated broodstocks succeded spawned in the controlled concrete tank. After approximately $1 \mathrm{wk}$ incubation, the orange color eggs attached on the abdominal crab turned into darkish and hatched in to zoea 1 larvae stage. This incubation period was similar as reported by Arshad et al. (2006) that incubation period of blue crab embryo was $8 \mathrm{~d}$ at $28^{\circ} \mathrm{C}$. Color of blue crab eggs changed follows embryo development. Color of newly spawned eggs was orange then the color turned to yellow at day 2, brownish at day-3, brown at day-4, blackish brown at day-5, dark grey at day- 6 and finally the color changed to black grey at day 7 and 8 . This color changes indicated embryo development process and black color was a sign of embryo eyes has well developed occupy the space inside the egg that ready to hatch (Ravi and Manisseri, 2013).

Size of broodstock affects eggs fecundity, hence influences number of hatched larvae (Table 3). According to Arshad et al. (2006), that weight of eggs mass is positively correlates to fecundity, the output of reproduction. Fecundity of blue crab at size of $102.25-140.58 \mathrm{~mm}$ CW varied from 148,897-835,401 eggs. Table 3 shows reproductive productivity of both types of broodstocks was relatively different eventhough the carapace width and weight of eggs mass of domesticated broodstock was bigger but number of hatched larvae relatively low. Each gram of eggs mass of domesticated broodstock produced 22,000 larvae in average while wild broodstock produced 33,000 larvae.

Daily observation showed that there was a differences on the stage transition developement of both groups of larvae from both broodstocks sources (Table 4). Larvae from domesticated broodstock required $2,2,2,3 \mathrm{~d}$ in average developement to zoea-1, 2, 3, and 4 respectively. While, larvae from wild broodstock needed 2, 3, 3, $3 \mathrm{~d}$ for transformation to zoea-1, 2, 3, and 4. In general, larvae from domesticated broodstock reached megalopa phase on day-10 and crab phase on day-14, while larvae from wild broodstock attained megalopa phase on day-12 and crab phase on day-16. Previous studies have shown that larvae from wild broodstock exposed to various treatments attained megalopa phase on day-11-14 (Arshad et al., 2006), day-12-13 (Redzuari et al., 2012) and day-12-15 (Ikhwanuddin et al., 2012 ${ }^{\mathrm{a}}$ ). Other study of Ikhwanuddin et al., $\left(2012^{\mathrm{b}}\right)$ in which larvae were reared at various density from 50-300 larvae per litre, they found the larvae reached megalopa phase on day-13. Josileen and Menon (2004) also reported that crab-1 stage of blue crab was attined on day15-17. These all founding indicated that domesticated broodstock-raised larvae developed faster compared to the wild broodstock-raised larvae.

In addition to the characteristic of faster growth of the larvae from domesticated broodstock, the crab also developed uniformly in each stage transition. Table 4 shows on day- $10.80 \%$ of zoea population had transformed into megalopa phase, and on day-12, all zoea larvae completed their development into megalopa phase. However, the larvae from wild broodstock, on day-12, only $10 \%$ of the larvae reached megalopa phase, and all larvae completed their transition into megalopa phase on day-14. Longer time in larval development has bad impact on survival rate (Figure 1). 
Table 3. Reproductive data of domesticated and wild blue crab broodstocks

\begin{tabular}{ccccccc}
\hline Broodstock No & $\begin{array}{c}\text { Carapace } \\
\text { width }(\mathrm{mm})\end{array}$ & $\begin{array}{c}\text { Weight } \\
\text { (berried) }(\mathrm{g})\end{array}$ & $\begin{array}{c}\text { Weight } \\
\text { (spent) }(\mathrm{g})\end{array}$ & $\begin{array}{c}\text { Mass eggs } \\
\text { weight }(\mathrm{g})\end{array}$ & $\begin{array}{c}\text { Number } \\
\text { of Zoea }\end{array}$ & $\begin{array}{c}\text { Zoea / g } \\
\text { eggs }\end{array}$ \\
\hline Domesticated & & & & & & \\
1 & 128 & 181 & 148.9 & 32.1 & 630,400 & 19,638 \\
2 & 132.2 & 154.2 & 124.4 & 2.8 & 723,538 & 24,279 \\
3 & 128 & 167.8 & 149.3 & 18.5 & 434,600 & 23,491 \\
4 & 128 & 160.6 & 131 & 29.6 & 654,900 & 22,125 \\
\hline Mean & $\mathbf{1 2 9 . 0}$ & $\mathbf{1 6 5 . 9}$ & $\mathbf{1 3 8 . 4}$ & $\mathbf{2 6 . 7}$ & $\mathbf{6 1 0 , 8 5 9}$ & $\mathbf{2 2 , 3 8 3}$ \\
\hline Wild & & & & & & \\
1 & 106.6 & 88.7 & 74.2 & 14.5 & 424,307 & 29,262 \\
2 & 105.6 & 86 & 73.8 & 12.2 & 539,242 & 44,200 \\
3 & 103.1 & 83.1 & 67 & 16.1 & 516,903 & 32,105 \\
4 & 92.4 & 53.6 & 44.3 & 9.3 & 250,700 & 26,956 \\
\hline Mean & $\mathbf{1 0 1 . 9}$ & $\mathbf{7 7 . 8}$ & $\mathbf{6 4 . 8}$ & $\mathbf{1 3 . 0}$ & $\mathbf{4 3 2 , 7 8 8}$ & $\mathbf{3 3 , 1 3 1}$ \\
\hline
\end{tabular}

Table 4. Larval stage index (LSI) of crab larva of domesticated and wild broodstock blue crab

\begin{tabular}{ccccc}
\hline \multirow{2}{*}{ Age $(\mathrm{d})$} & \multicolumn{2}{c}{ Domesticated broodstock larva } & \multicolumn{2}{c}{ Wild broodstock larva } \\
\cline { 2 - 5 } & LSI & Stages & LSI & Stages \\
\hline 1 & 1.0 & $\mathrm{Z} 1$ & 1.0 & $\mathrm{Z} 1$ \\
3 & 1.0 & $\mathrm{Z} 1$ & 1.0 & $\mathrm{Z} 2$ \\
4 & 1.9 & $\mathrm{Z} 2$ & 1.2 & $\mathrm{Z} 2$ \\
5 & 2.0 & $\mathrm{Z} 2$ & 2.0 & $\mathrm{Z} 2$ \\
6 & 2.3 & $\mathrm{Z} 3$ & 2.0 & $\mathrm{Z} 3$ \\
7 & 3.0 & $\mathrm{Z} 3$ & 2.1 & $\mathrm{Z} 3$ \\
8 & 3.4 & $\mathrm{Z} 4$ & 3.0 & $\mathrm{Z} 4$ \\
9 & 4.0 & $\mathrm{Z} 4$ & $\mathrm{Z} 4$ \\
10 & 4.0 & $\mathrm{Z}$ & 3.0 & $\mathrm{Z} 4$ \\
11 & 4.8 & $\mathrm{M}$ & 3.2 & $\mathrm{M}$ \\
12 & 5.0 & $\mathrm{M}$ & 4.0 & $\mathrm{M}$ \\
13 & 5.0 & $\mathrm{M}$ & 4.0 & $\mathrm{M}$ \\
14 & 5.0 & $\mathrm{M}$ & 4.1 & $\mathrm{M}$ \\
15 & 5.3 & $\mathrm{C}$ & 4.2 & $\mathrm{C}$ \\
16 & 6.0 & $\mathrm{C}$ & 5.0 & $\mathrm{C}$ \\
17 & 6.0 & $\mathrm{C}$ & 5.0 & $\mathrm{C}$ \\
\hline
\end{tabular}

Note : Z1 : zoea-1, Z2 : zoea-2, Z3: zoea-3, Z4 : zoea-4.

Grey shading rows indicates : there are two stages of larvae in the tank at the same day

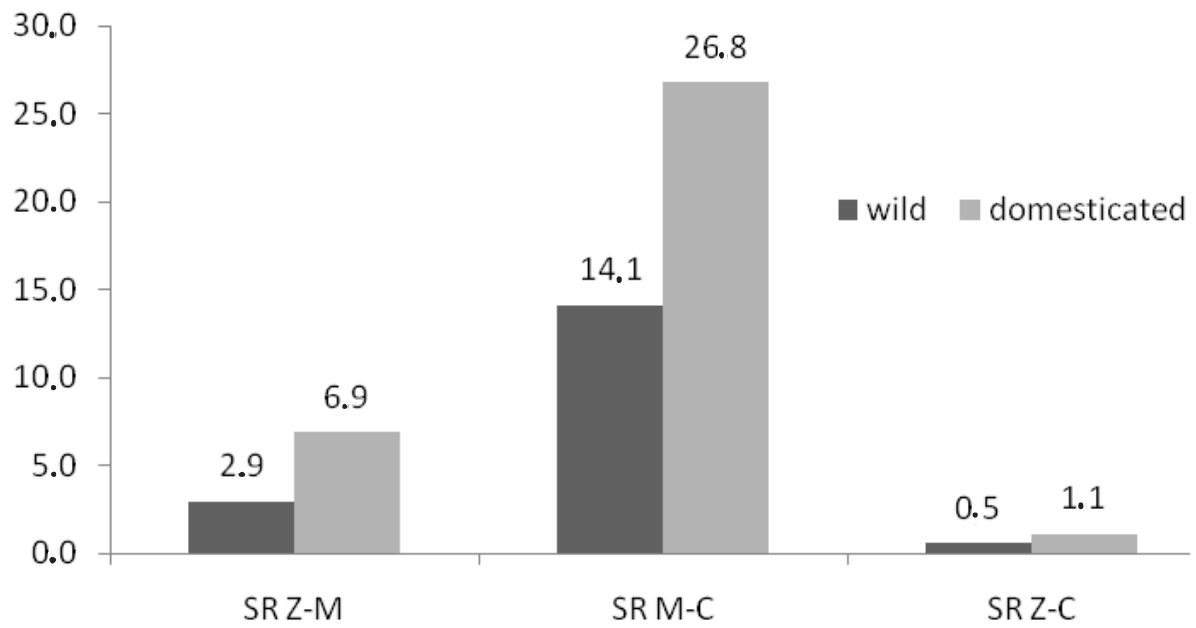

Figure 1. Survival rate of crab larvae from domesticated and wild broodstock during zoea - megalopa phases. Notes : SR : survival rate, Z : zoea, M : megalopa, C : crab 
In general, final survival rate of larvae from domesticated broodstock was considerably low, but survival rate during zoea phase was significantly higher $(P<0.05)$ than that of larvae from wild broodstock. Similar trend was also observed in the period of lavae from megalopa to crab instar 5 (C-5). Hence, number of crab can be harvested from domesticated broodstock was higher compared to the larvae from wild broodstock $(P<0.01)$. This result showed that there is a big opportunity for development of blue crab hatchnery technology in the future. Use of domesticated broodstock can produce high quality of crab larvae that able to adapt and survive in the fluctuated rearing environment. Through domestication, natural selection occurs, animal can adapt to their rearing environment and produce qualified and higher number offspring (Hoar, 2009). Then these offspring perhaps able to grow better and resistant to diseases, thus increase productivity (Gjedrem and Baranski, 2009).

Soundarapandian et al. (2007), proposed that mortality and cannibalism are the main problems in the production of blue crab seed. In this study high mortality occurred in the beginning larval period until day-5, especially on the transition from zoea- 1 to zoea- 2 then zoe- 2 to zeoa-3. Christiansen and Costlow (1975) observed the reason of high mortality occurred in the larvae of mudcrab at premetamorphic stage. In this stage the larvae was more extremely susceptible to fluctuated environmental conditions. The metabolic cost of metamorphosis is very high and appears to decrease the capacity of the larvae to counteract these unfavourable conditions.

Larvae live in the water media are very sensitve to the changes of water quality and easily become stress and weak, they can not maintain their position in the water column then cause them to sink to the bottom of the tank, and forming dense clumps. When the larvae aggregated on the tank bottom, and normally water quality at the tank bottom is poor than on the top layer, it is easily infected by pathogen or the larvae are prone to damage because they attach to each other. Other factor contributes to the mortality is molting inability of crab larva (Jamari, 1992). This may caused by chitin damage infected by bacteria or fungi on the larva carapace (Hamasaki et al., 2002).

Fujaya et al. (2014) also suggests that in addition due to molting syndrome and cannibalism, mortality was also caused by fungal attack, abnormal morphology, and the factors that have not been identified but it was assumed mainly due to water quality, feed and broodstock. More than $\pm 57 \%$ mortality of blue crab larvae can not be identified because there was no damage in morphology, $\pm 17 \%$ due to attack by fungi and parasites, and $\pm 15 \%$ due to cannibalism.

Temperature has a very strong influence on survival rate (Bryars and Havenhand, 2006; Ikhwanuddin et al., $2012^{\mathrm{c}}$ ). Bryars and Havenhand (2006) found that crab larva reached highest survival rate at temperature of $25^{\circ} \mathrm{C}$ (the highest temperature treatment on his study). In the temperature region like in Gulf St. Vincent, South Australia, peak hatching time occurs during summer season, precisely in from middle of December to February when the temperature at $22-23^{\circ} \mathrm{C}$. On that period, larva development takes $4 \mathrm{~d}$ for zoea-1, more than $5 \mathrm{~d}$ for zoae- 2 to zoea- 4 and more than $8 \mathrm{~d}$ for megalopa phase. That was the reason why highest survival rate found on that study at the temperature of $25^{\circ} \mathrm{C}$. However, other study in Malaysia found that the highest survival rate of blue crab larvae at the temperature of $30^{\circ} \mathrm{C}$ (Ikhwanuddin et al., 2012 ).

Salinity is also has a significant effect on the survival and growth of early stage juvenile P. pelagicus (Romano and Zeng, 2006). They reported that outside the range of $20-35 \%$ salinity significantly decreased survival rate, growth and development of early juvenile blue swimmer crab. This is due to the high metabolic cost of osmoregulation on condition of hyper and hypo-osmotic. It was reported that salinity of $25 \%$ was the best in supportting survival rate of early stage juvenile $P$. pelagicus. Other study showed that optimum salinity for $P$. pelagicus larvae was 30\%o (Ikhwanuddin et al., 2012 ${ }^{\mathrm{c}}$ ).

In this study, the temperature ranges between $26-32^{\circ} \mathrm{C}$ and salinity $31-33 \%$. The temperature range seems risky for survival rate and development of the crab larvae. Fluctuations in temperature was high, especially the daily fluctuations between the morning and afternoon. This study was conducted in the backyard hatchery with very simple building construction with plastic tarpaulin roof and limited amount freshwater. This condition may cause high fluctuation of temperature. Use of heater and chiller are needed to stabilize the temperature. While salinity needs to be reduced using freshwater.

Feed is another most important factor to support survival, development and growth of crab 
larvae. In this study, two types of natural feed was used, rotifers and Artemia nauplii, in combination with artificial feed. Live food is still the first choice in most hatcheries. Live food guarantees availability of nutrients for the larvae and it's enzymes content facilitate digestive process more efficient in the larvae (Chen and Lin, 1992). Since important enzyme has not been developed before zoea- 3 of the blue crab larvae (Nikhlani, 2013), exogenous enzyme from live food is important in assisting digestion process.

Application of artificial diet is expected to supply additional nutrients needed for larvae which is less avaiable in live food like EPA and DHA. less available in natural food rotifers and Artemia as EPA and DHA (Conceicao et al., 2010). In addition, early application of diet may accelerate feed exchange from live food to artificial diet. In the crab hatchery, artificial diet is more efficient in preparation and its management. Mass culture of live food is very much depending on the weather (Smith, 1988). In addition, price of Artemia is very expensive, that may take $50 \%$ of crab hatchery operational cost (Quinitio et al., 2001).

\section{Conclusion}

This study concludes that the use of domesticated broodstock is a great opportunity for development of blue crab aquaculture in the future. The use of domesticated broodstock followed by proper and consistent operational procedure will produce high survival and growth of larvae. Maintain good water quality and good management of broodstock and feeding may prevent the larvae from stress, malnutrition and disease problems.

\section{Acknowledgements}

This study was financially supported by the Ministry of Education and Culture of Republic of Indonesian for the funding through Grant for Excellent Research of National Strategic. The authors wish to thanks Faculty of Marine Sciences and Fisheries Hasanuddin University for the use of the facilties.

\section{References}

Arshad A., Efrizal, M.S. Kamarudin, and C.R. Saad. 2006. Study on fecundity, embryology and larval development of blue swimming crab Portunus Pelagicus (Linnaeus, 1758) under laboratory conditions. Research Journal of Fisheries and Hydrobiology, 1(1):35-44.

Bryars, S.R. and J.N. Havenhand. 2006. Effects of constant and varying temperatures on the development of blue swimmer crab (Portunus pelagicus) larvae: laboratory observations and field predictions for temperature coastal waters. J. of Experimental Marine Biology and Ecology, 329: 218-229.

Chen H.Y. and H.F Lin. 1992. Effects of different Artemia diets on the growth and digestive enzyme activities of early post-larval Penaeus monodon. Asian Fish. Sci., 5: 73-81.

Christiansen, M.E. and J.D. Costlow, Jr. 1975. The effect of salinity and cyclic temperature on larval development of the mud crab Rhithropanopeus harrisii (Brachyura: Xanthidae) reared in the laboratory. Mar. Biol., 32: $215-221$.

Conceicao, L.E.C., M. Yuvera, P. Makridis, S. Morais, and M.T. Dinis. 2010. Live feeds for early stages of fish rearing. Aquaculture research, 41: 613-640.

FAO. 2014. A species fact sheets Portunus pelagicus (Linnaeus, 1758). Fisheries and Aquaculture Department. FAO UN.

Fujaya, Y., D.D. Trijuno, A. Nikhlani, I. Cahyono, and Hasnidar. 2014. The use of mulberry (Morus alba) extract in the mass production of blue swimming crab (Portunus pelagicus L.) larvae to overcome the mortality rate due to molting syndrome. Aquatic Science and Technology, 2 (1): 1-14.

Gjedrem, T. and M. Baranskii. 2009. Selective Breeding in Aquaculture: An Introduction. Springer Science+Business Media B.V. New York.

Hale, E.B., 1969. Domestication and the evolution of behavior. In: Hafez, ESS. (Ed.) - The behavior of Domestic Animals. Bailliere, Tindall and Cassell, London, pp. 22-42.

Hamasaki, K., M.A. Suprayudi, and T. Takeuchi. 2002. Effect of dietary n-3UHFA on larval morphogenesis to megalopa in the seed production of mud crab (Scylla serrata) (Brachyura: Portunidae). Suisanzoshoku, 50: 333-340.

Hassin, S., D. De Monbrison, Y. Hanin, A. Elizur, Y. Zohar, and D.M. Poper. 1997. Domestication of the white grouper, Epinephelus aeneus. 1. Growth and reproduction. Aquaculture, 156: 305-316.

Hoa, N.D., 2009. Domestication of black tiger shrimp (Penaeus monodon) in recirculation systems in Vietnam. Ph.D thesis, Ghent University, Belgium.

Ikhwanuddin, M., J.H. Mansor, A.B. Abol-Munafi, and M.L. Shabdin. 2012 ${ }^{\mathrm{a}}$. Improved hatcheryrearing techniques for juvenile production of blue swimming crab, Portunus pelagicus 
(Linnaeus, 1758). Aquaculture Research, 43:1251-1259.

Ikhwanuddin, M., A.D. Talpur, M.N. Azra, B.M. Azlie, Y.S. Hii, and A.B. Abol-Munafi. $2012^{\mathrm{b}}$. Effects of stocking density on the survival, growth and development rate of early stages blue swimming crab, Portunus pelagicus (Linnaeus, 1758) larvae. World Applied Sciences Journal, 18(3):379-384.

Ikhwanuddin, M., M.N. Azra, A.D. Talpur, A.B. Abol-Munafi, and M.L. Shabdin. 2012 Optimal water temperature and salinity for production of blue swimming crab, Portunus pelagicus 1st day juvenile crab. Aquaculture, Aquarium, Conservation \& Legislation, 5(1):4-8

Jamari, Z.B. 1992. Preliminary studies on rearing the larvae of the mud crab (Scylla serrata) in Malaysia. The mud crab culture and trade held at Surat, Thani, Thailand, Nov. BOBP. pp. 135-141.

Josileen, J. and N.G. Menon. 2004. Larval stages of the blue swimmer crab, Portunus pelagicus (Linnaeus, 1758) (Decapoda, Brachyura). Crustaceana, 77:785-803.

Lai, J.C.Y., K.L.Ng, Peter, and J.F.D. Peter. 2010. A revision of the Portunus pelagicus (Linnaeus, 1758) species complex (Crustacea: Brachyura: Portunidae), with the recognition of four species. The Raffles Bulletin of Zoology, 58 (2): 199-237.

Nikhlani, A. 2013. Time Schedule determination of phytoecdysteroid on artificial feeding to overcome moulting syndrome on metamorphosis of Blue Swimming Crab larvae (Portunus pelagicus). Dissertation. Post Graduate Programe Hasanuddin University. Makassar Indonesia.
Quinitio, E.T., F.D. Parado-Estepa, O.M. Millamena, E. Rodriguez, E. Borlongan. 2001. Seed production of mud crab Scylla serrata juveniles. Asian Fisheries Science, 14:161-174.

Ravi, R. and M.K. Manisseri. 2013. The effect of different $\mathrm{pH}$ and photoperiod regimens on the survival rate and developmental period of the larvae of Portunus pelagicus (Decapoda, Brachyura, Portunidae). Iranian Journal of Fisheries Sciences, 12(2):490-499.

Redzuari, A., M.N. Azra., A.B. Abol-Munafi, Z.A. Aizam, Y.S. Hii, and M. Ikhwanuddin. 2012 Effects of Feeding Regimes on Survival, Development and Growth of Blue Swimming Crab, Portunus pelagicus (Linnaeus, 1758) Larvae. World Applied Sciences Journal, $18(4): 472-478$

Romano N. and C. Zeng. 2006. The effects of salinity on the survival, growth and haemolymph osmolality of early juvenile blue swimmer crabs, Portunus pelagicus. Aquaculture, 260:151-162.

Smith, D.W. 1988. Phytoplankton and catfish culture: a review. Aquaculture, 74:167-189.

Soundarapandian, P., E. Tamizhazhagan, and N.J. Samuel. 2007. Seed production of commercially important blue swimming crab Portunus pelagicus (Linnaeus). Journal of Fisheries and Aquatic Science, 2(4) : 302-309.

Williams, M.J. and J.H. Primavera. 2001. Choosing tropical portunid species for culture, domestication and stock enhancement in IndoPacific. Asian Fish. Sci., 14: 121-142.

Wyban, J. 2007. Domestication of Pacific White Shrimp revolutionizes aquaculture. Global Aquaculture Advocate, 42-44. 